\title{
Tesauro da língua portuguesa
}

Solange Puntel Mostafa

Curso de Ciências da Informação e Documentação - USP, Ribeirão Preto Email: smostafa@terra.com.br

\section{AZEVEDO, Francisco Ferreira dos Santos. Dicionário analógico da língua portuguesa:} idéias afins/ thesaurus. 2. ed. atual. rev. Rio de Janeiro: Lexikon, 2010. 800 p.

O Dicionário analógico da língua portuguesa. é uma obra singular dentro da lexicologia brasileira; a obra está em sua segunda edição após sessenta anos de sua publicação original. $\mathrm{Na}$ abertura da obra, o surpreendente depoimento de Chico Buarque de Holanda sobre os dicionários de seu pai, Sérgio Buarque de Holanda enche o leitor de curiosidade. Chico conta ter sido apresentado ao dicionário analógico, em sua primeira edição, por seu pai: "Com esse livro escrevi novas canções e romances, decifrei enigmas, fechei muitas palavras cruzadas" (p. v).

No prólogo da obra, Leodegário A. de Azevedo Filho saúda a editora Lexicon por entender que, apesar da língua portuguesa ter sido contemplada com excelentes dicionários, tanto em Portugal como no Brasil, nada se assemelha a este, de caráter analógico.

A obra apresenta ainda instruções de uso, índice alfabético geral das palavras empregadas no final, como em qualquer livro, bem como um quadro sinóptico de categorias, sob as quais está reunido o corpus. O quadro sinóptico das categorias inclui seis grandes classes, a saber: Relações abstratas, Espaço, Matéria, Entendimento, Vontade e Afeições. Chamamos categorias, o campo de associações de uma palavra.

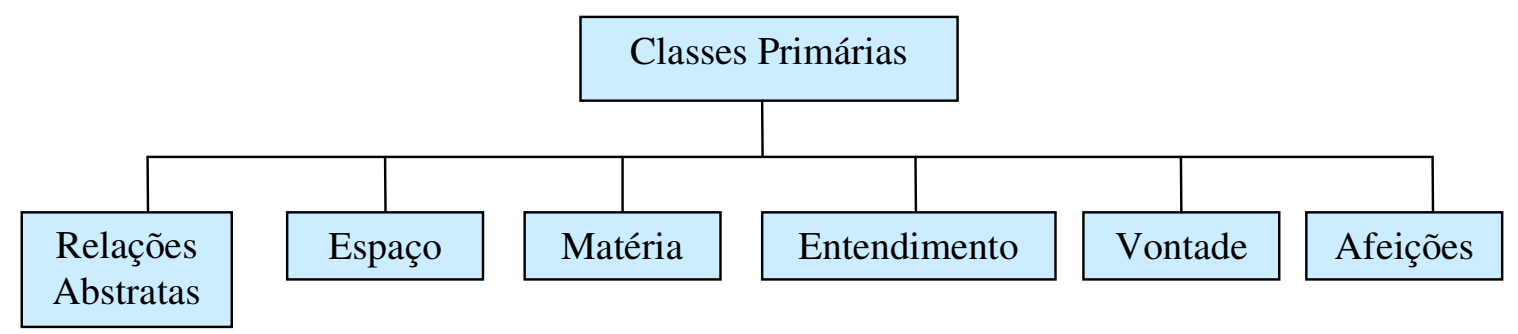

Cada uma dessas classes apresenta divisões numeradas pelos termos que abrange. Para simplificar o uso de tal obra, o leitor apenas deve procurar no índice alfabético do final da 
obra, com uma palavra aproximada do que deseja, e esta lhe oferecerá, no interior da obra, toda uma rede semântica de palavras análogas ou relacionadas.

No dicionário de línguas que comumente consultamos, procuramos o significado da palavra que já conhecemos; no dicionário analógico é o contrário: ainda não conhecemos a palavra correta para designar o sentido do que queremos expressar. Também denominado thesaurus, o dicionário analógico oferece várias palavras análogas a que estamos procurando, numa espécie de nuvem semântica, em graus de proximidade diferenciados à palavra que buscamos. O relato de Cláudio Moreno abaixo é ilustrativo; o professor Moreno relata que alvinegro é o termo designativo das cores branca e preta de clubes de Futebol, como Corinthians, em São Paulo, ou Vasco da Gama no Rio de Janeiro. Como alvinegro, temos também rubro-negro e vários outros termos tradicionais da heráldica, para designar os times de futebol. Imagine agora que o leitor quisesse se lembrar do termo designativo da cor amarela atribuída ao clube de futebol grêmio Bagé, time do interior do Rio Grande do Sul; onde procurar?

\begin{abstract}
abri o dicionário analógico na grande categoria das cores e fui direto à seção do amarelo. Como eu não conhecia a palavra, comecei a ler em voz alta todos os itens da relação até que - bingo! - todos saltaram quando cheguei a jalde (que, como averigüei mais tarde, é o esquisito nome que a heráldica usa para amarelo). Era a resposta: o Grêmio Bagé era tratado na crônica desportiva como 'o jalde-negro' (http://pessoailtda.blogspot.com/2010/06/dicionario-analogico-da-lingua.html)
\end{abstract}

O relato acima dá bem a dimensão do que é um dicionário analógico ou um thesaurus de língua. Diferente de um dicionário comum que busca o significado das palavras, uma vez encontradas na ordem alfabética, o dicionário analógico ou thesaurus reúne um conjunto de palavras semanticamente relacionadas.

O primeiro do gênero foi desenvolvido por Peter Mark Roget, médico inglês do século dezenove, secretário da Royal Society, que criou para seu próprio uso, um catálogo de palavras classificado por grandes categorias. Roget é bem conhecido dos bibliotecários e cientistas de informação, por ser uma obra que inspirou os tesauros temáticos das áreas de especialidade, desde a década de setenta. Tanto o thesaurus de Roget quanto o da Língua Portuguesa, funcionam como sistemas de classificação, uma vez que delineiam grandes categorias para abrigar as palavras, relacionando-as.

$\mathrm{Na}$ área de biblioteconomia e ciência da informação em que os tesauros são temáticos, são bem conhecidas as categorias propostas por Ranganathan, como Personalidade, Matéria, Energia, Espaço e Tempo (PMEST). Os bibliotecários e cientistas da informação têm InCID: R. Ci. Inf. e Doc., Ribeirão Preto, v. 1, n.1, p. 184-186, 2010. 
desenvolvido centenas de tesauros temáticos que são as linguagens documentárias mais comuns não só para as áreas de ciência e tecnologia, como também para as áreas de humanidades e até para literatura (veja por exemplo o Vocabulário controlado para indexação de obras ficcionais, publicado pela Briquet Lemos editora).

Dessa forma, esse Dicionário analógico da língua portuguesa interessa não apenas a todos os falantes da língua portuguesa do Brasil e de Portugal, como nas cinco nações africanas, Angola, Cabo Verde, Guiné Bissau, Moçambique e São Tomé e Príncipe. Sua leitura também auxilia bibliotecários e cientistas de informação dessas nações, bem como aos docentes de Linguagens documentárias, na medida em que oferece aos alunos possibilidades de vivenciar um tesauro de línguas, em português, semelhante ao da língua inglesa idealizado por Roget, comumente apresentado na literatura de Linguagem documentária. 